\title{
12
}

\section{Of Pizza Ovens in Arnhem Land: The State Quest to Restructure Aboriginal Labour in Remotest Australia}

\author{
Jon Altman
}

\section{Preamble}

In contemporary Australian policy, and especially Indigenous policy, little distinction is made between labour, work, employment and jobs. In fact, most of the focus is on formal or paid employment. Consequently, in the last decade, we have seen the emergence of employment policy with the overarching goal to 'close', or at least reduce, the gap in formal employment outcomes between Indigenous and non-Indigenous Australians. As the 10th annual Closing the Gap report recently tabled in the Australian Parliament clearly demonstrates, this goal-first articulated by Kevin Rudd in 2008 as an element of the National Apology to the Stolen Generations and then adopted by the Council of Australian Governments that yearhas failed. The goal was to halve the gap at the national level in what is technically termed the 'employment to population ratio' between 2008 and 2018. ${ }^{1}$ This goal has not only failed nationally, but also, and most spectacularly, in the 86 per cent of the Australian continent that is defined officially as remote and very remote; the latest census of 2016 indicates

1 Commonwealth of Australia, Closing the Gap. 
that, in very remote Australia, only three in 10 Indigenous adults are in some form of paid employment compared to eight in 10 non-Indigenous adults. This is not a gap, it is a gulf.

In a 30-year period from the early 1970 s, the unusual circumstances of remote Indigenous Australia were recognised by policymakers and, consequently, some programs were designed to accommodate the absence of formal commercial and employment opportunity. However, in the twenty-first century, as neoliberal thinking and associated valorisation of the free market became ascendant, policy discourse and practice changed. There is a growing expectation that remote-living Indigenous people will find mainstream employment and that the welfare dependency and social dysfunction attributed to such dependency will decline and disappear. This expectation accelerated rapidly after the Northern Territory National Emergency Response (the 'Intervention') in 2007 and governmental insistence that the norms and values of remote-living Aboriginal people should alter to embrace mainstream values of neoliberal individualism. It was never made clear how such an embrace of Western norms would generate paid employment in remote places, but the logical options are threefold: local Aboriginal people would take the jobs held by non-local, non-Aboriginal people; remote economies would grow and so generate more paid employment; jobless people would move to places where there are more jobs (see Prout Quicke and Haslam McKenzie, and Neale, in this volume).

In this chapter, I home in on the last issue of anticipated labour mobility for employment as the least likely option for the Aboriginal people with whom I have worked over the past four decades in very remote localities where there are few or no paid jobs. I know one place, an outstation in western Arnhem Land in the Northern Territory called Mumeka, extremely well. I lived there in 1979 and 1980 and have visited almost every year since. Much of my work as an anthropologist has been with people who constitute a community defined, in part, by their traditional ownership of the area around Mumeka and, in part, by their shared use of Kuninjku, a dialect of a regional pan-dialectical language called Bininj Kunwok. ${ }^{2}$ The only paid employment at Mumeka for a long time now has been for a teaching assistant. To get paid employment, Mumeka residents

2 Garde, Culture, Language and Person Reference. 
have either to migrate to the nearby township of Maningrida, where there are few available jobs, or further afield, or somehow economically develop their outstation and surrounds to generate jobs.

I begin this chapter by revisiting some observations on a brief visit to Mumeka in July 2012 that, six years on, I interpret as a pivotal moment when I saw a particular form of economic development being introduced. I have made several presentations between 2012 and 2014 using this ethnographic material but, for a variety of reasons that will become apparent as the narrative unfolds, including disbelief at what I was observing, I have not published this material until now. ${ }^{3}$

I commence with an observation about remote development for employment and then try to make some analytic sense of this. I look to provide some historical and regional contexts for what I saw. I then explore Kuninjku regimes of work under colonial conditions and in the postcolonial present, and examine some possible explanatory theories for interpreting a form of recolonisation that is occurring in the name of modernising development and employment creation. I end with a postscript that provides a brief update of the consequences that have unfolded since that pivotal moment to which I now turn.

\section{Mumeka, July 2012}

As I thundered along the bone-jarring dirt road officially classified as a 'flat-bladed track' (that had clearly not seen a blade for some time) towards the Aboriginal township of Maningrida in west Arnhem Land, I pondered what issues might await me in this region where I had worked since 1979. As usual, my head was full of ideas and too many projects.

3 I have circled around these issues elsewhere in Altman, 'Bawinanga and CDEP'; Altman, 'Basic Income for Remote'; Altman, "'The Main Thing”". This chapter builds on collaborations with the UK Economic and Social Research Council funded 'Domestic Moral Economy' project based at the University of Manchester, from 2011 to 2015. I would like to foremost thank many Kuninjku people in the Maningrida region for their collaborations over many years; Elisabeth Yarbarkhsh for research assistance; Jörg Wiegratz and Chris Gregory for stimulating interactions; and Murray Garde, Chris Haynes, Tim Rowse and especially Melinda Hinkson, as well as many others for stimulating comments and challenges during various presentations made in Cairns, Canberra, Brisbane, Tokyo and Wellington. 
This was my 48th visit to the region in 33 years (1979-2012). Increasingly, my so-called 'field work' involved catching up with old friends and their families, commiserating about departed relatives, and just talking in very concrete ways, as is local custom, about family (theirs and mine), ceremony, places and hunting, and the latest manifestation of settler colonial incursion into the Kuninjku community. I was undertaking what I increasingly think of as random 'spot check' field work reminiscent of some of the time allocation techniques I used when I was a doctoral student residing at Mumeka.

I pulled into Mumeka and parked my vehicle where I always stop, a safe and courteous distance from the house of senior traditional owner Iyuna (now deceased) and was warmly greeted as always. I looked around. There is always something happening at Mumeka, and I saw that the outstation surrounds had been drastically cleared, not by fire as is the usual practice in the dry season, but by some flat-bladed instrument attached to a tractor.

I asked my friends what was going on here. There were numerous flat packed cardboard boxes neatly stacked, mudbricks, a brand-new rideon lawnmower, rakes, brooms, plastic wheelie bins, a generator and manifestations of construction. 'We are all on "new CDEP"' my friends cheerily told me, referring to the Community Development Employment Projects (CDEP) scheme that many had engaged with for over a decade and that was currently being unilaterally and radically reformed by the Australian state. 'We are making vege [vegetable] gardens and barbeques, [a] pizza oven and chicken houses [coops]'. 'To eat?' I asked, for these are extraordinary meat-eating hunters. 'Kayakki, dabuno [no way, for eggs!]', they answered. 'We are getting five new houses' (to supplement two modern houses at Mumeka shared by about 30 people), added Jimarr, 'and a service station to provide diesel for overland travellers' (as a new enterprise). 'Really', I said, 'waybukki, true story?' 'Yo, waybukki, was the reply. Development, it seemed, was coming to Mumeka.

I drove on to Maningrida, the regional township and services centre, with some trepidation. While I know many people there, this larger township is never as serene as Mumeka and can often be politically turbulent. My point of articulation with Maningrida is the Bawinanga Aboriginal Corporation (BAC) that I have worked with since its establishment as an outstation resource agency in 1979. BAC has been extremely successful as an Aboriginal organisation. It is the largest in the Northern Territory; however, since the Intervention, it has struggled, experiencing four changes 
of CEO, with the latest having just been sacked by the all-Aboriginal board, and an unprecedented turnover of staff. In an organisational and historical sense, I probably knew more about BAC than any of its current staff or board. Whatever was happening at Mumeka would be driven by BAC and I braced myself to explore the thinking behind this latest development - the notion that highly mobile people could be transformed to tend gardens, raise chickens and even run service stations, all forms of labouring that required sedentary living and labouring.

\section{Policy and Regional Contexts}

My visit to Mumeka coincided with the completion of the five-year Intervention that sought to morally restructure the norms and values of remote-living Aboriginal people. In June 2012, when this project neared its end date without having achieved its aims, it was extended for a further 10 years and rebadged as Stronger Futures for the Northern Territory. ${ }^{4}$ This is an ongoing paternalistic effort to align Aboriginal ways of living with those of the dominant mainstream. The public discourse around Aboriginal dysfunction and subsequent associated policy settings were the culmination of a fundamental policy shift that effectively declared selfdetermination dead and mainstreaming or assimilation as the way ahead for Aboriginal people. ${ }^{5}$

This project of moral restructuring was also encapsulated from 2008 in a policy framework called Closing the Gap. Although promulgated as a national project, the policy was poorly conceptualised for remote circumstances and took little account of history or possible Aboriginal responses and resistance to it. It was the latest in a long line of visionary social engineering exercises that looked to discipline the behaviour of Aboriginal workers, parents and welfare recipients to ensure greater employment participation, higher school attendance, better parenting and more responsible spending patterns. ${ }^{6}$ Clearly, in such impositions,

4 The Stronger Futures in the Northern Territory Act 2012 is available at www.legislation.gov.au/ Details/C2012A00100 (accessed 15 March 2019). In 2015, with a change of federal government, anew National Partnership Agreement on Northern Territory Remote Aboriginal Investment (NTRAI) from 2015-16 to 2021-22 replaced the National Partnership Agreement on Stronger Futures in the Northern Territory.

5 Strakosch, Neoliberal Indigenous Policy.

6 Hinkson, 'Introduction: In the Name'. 
there are deeply embedded contests about ways of living and being, with the powerful state machinery discursively asserting the superiority of Westerns norms and values over Aboriginal ones.

I focus here on the Maningrida regional setting in west Arnhem Land and deploy my points of regional articulation with the Kuninjku community of about 300 people and with BAC to say something about transformations and political contestation with a focus on contested regimes of working. In situations of economic plurality or hybridity-entangled relations between Kuninjku people who strive to maintain elements of their customary hunting and gathering economy and a neoliberal state and market capitalism-different regimes of labouring-characterised as Balanda (non-Aboriginal) and Bininj (Aboriginal) or formal and informal/ paid and unpaid-have been evident since state colonisation. What is distinctive and at stake in the latest transformation is an increasing gulf between Bininj and Balanda perspectives even as the state is determined to close the employment gap.

One reason for this, in my view, is that, in looking to transform the labour relations of people like the Kuninjku, the state and its agents are oblivious to the extraordinary transformations that have already occurred as a result of Kuninjku adaptations to regional manifestations of state colonisation and capitalism. Further, in looking to statistically 'close the gap' between Indigenous and other Australians, there has been little attention paid to the actual nature of the local economy or its long-standing ethnic duality, or to the risk that, in aiming to close statistical gaps, local livelihoods and wellbeing might, in fact, be put at risk and decline.

The overarching observation that I develop below focuses on the growing incommensurability between the state's goal for remote-living Aboriginal people like the Kuninjku and what is desired by them and might be regionally possible. There is an intensifying political struggle underway about values and ways of living that I examine by focusing on the quest to transform residents of places like Mumeka into employed labour. In the context of this volume's focus on labour mobility (see especially Chapters 10 and 11), there is an ongoing struggle between the state and its agents looking to convert flexible and highly regionally mobile Kuninjku into regimented and sedentary workers, and Kuninjku responses to this imposition. 


\section{Kuninjku Labour Regimes: Pre- to Postcolonial}

Kuninjku people were among the last Aboriginal groups to be colonised in remote Australia; their pre-colonial lives in Arnhem Land residing in an Aboriginal reserve were only partially disrupted by occasional expeditions onto their traditional lands and the establishment of a mission at Oenpelli 200 kilometres to the west where some resided from the early twentieth century. It was the establishment of the more proximate Maningrida as a colonial outpost that directly affected their way of living. ${ }^{7}$

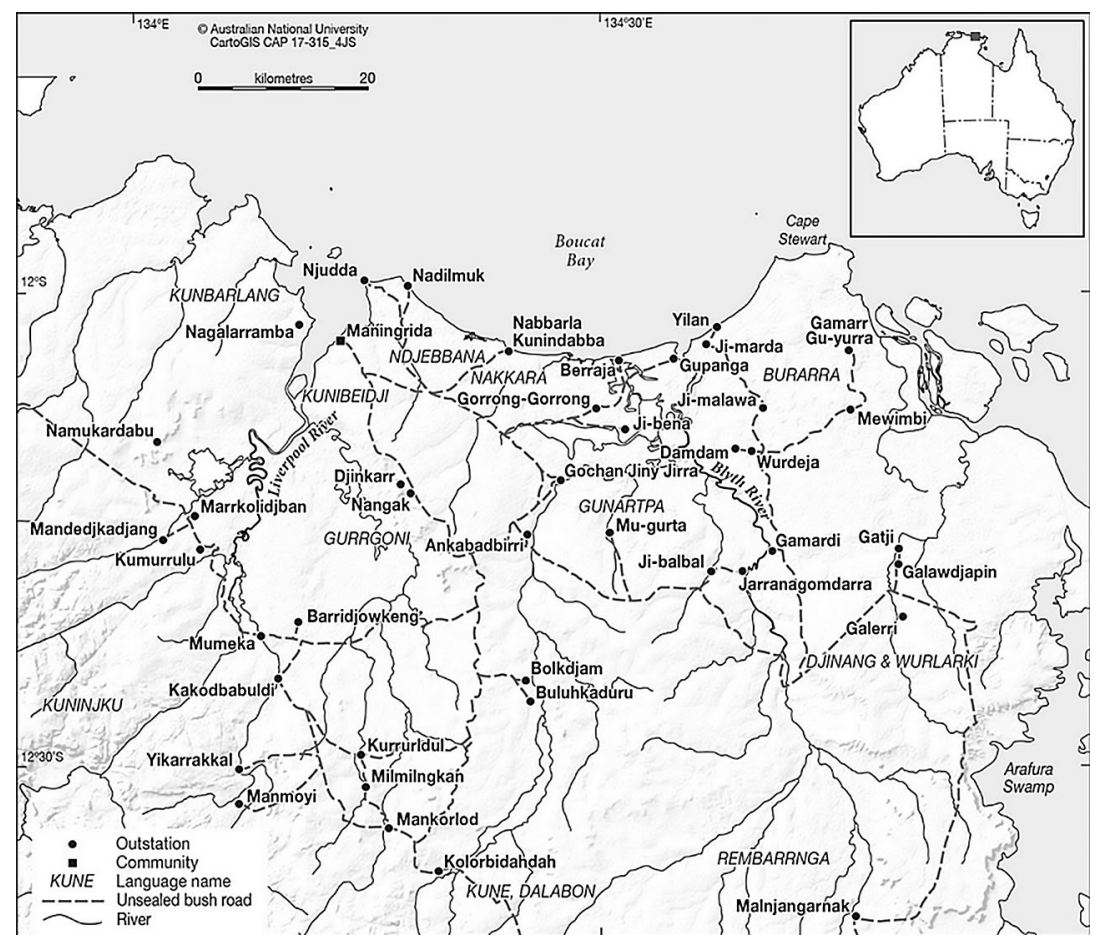

Figure 12.1: Map of the Maningrida region.

Source: CartoGIS, College of Asia and the Pacific, The Australian National University.

In 1949, a trading post was established at Maningrida by what was then the Native Affairs Branch of the Northern Territory administration as an instrument of controlling colonial policy. It was abandoned in 1950. In 1957, it was re-established, this time as a Welfare Branch settlement to create a colonial presence in a region of 10,000 square kilometres

$7 \quad$ Altman and Hinkson, 'Mobility and Modernity'. 
where none had previously existed. Government policy at that time was shifting from protection within a closed-off gazetted reserve to a quest to transform Aboriginal people to mainstream subjects via assimilation. Maningrida slowly developed into a township where Aboriginal people, as wards of the state, were to be trained for such assimilation through education, training and jobs, and the adoption of Western ways of living.

Historically, Maningrida failed as a project of assimilation for two main reasons. First, counter to capitalist logic, the settlement was established without any assessment of commodities that might flow from the hinterland. As it turned out, there were very few of any commercial value. Second, and again counter to capitalist logic, a series of development projects were established including forestry, cattle and buffalo raising, dairy, market gardens, orchards, flower propagation, fishing and fish processing, a piggery and chicken raising without any realistic appraisal of commercial viability or comparative advantage. All failed. ${ }^{8}$

Since 1957, Maningrida has had both Balanda and Bininj populations; it is a place of dual ethnicity but multiple language communities (see Figure 12.1). Up until the early 1970s, power was legally vested with Balanda officials as agents of the colonial state. In 1972, policy shifted dramatically from imposed assimilation to decolonising self-determination, which was initially viewed with great optimism by government as a way to empower Aboriginal people and to overcome earlier development failures. This history is important given that what I observed at Mumeka in July 2012 was arguably a microscopic simulacrum of what had occurred at Maningrida in the 1960s.

My focus on the Kuninjku mainly reflects my long-term research relationship with this group. Key distinguishing features of the Kuninjku community are that many of its members had late contact with the colonial state with some not moving to Maningrida until 1963. Kuninjku adapted poorly to settlement life and so, from the early 1970s, were among the first to decentralise and move to live on ancestral lands at tiny communities called outstations. Over time, their forms of residence have become more complicated and increasingly many live between the township and hinterland on a seasonal basis. In the last two decades, a number of Kuninjku people have settled at Maningrida on a more permanent basis for a range of reasons, such as employment, education for

8 Much of this history is available in expanded form in Altman, Hunter-Gatherers Today. 
children and access to health services; however, the permanence of such residential choice is difficult to assess given historic residential mobilitybush to town and vice versa.

Prior to their contact with the Australian colonial state, Kuninjku people mainly survived by highly mobile hunting, fishing and gathering, utilising what has been termed a kin-based domestic mode of production. ${ }^{9}$ Kuninjku adapted badly to Maningrida in part because they resisted, more actively than other groups, the expected transformation to Western forms of sedentary labouring for training allowances. Colonial officials frequently complained about their hyper-mobility back and forth from their traditional lands for ceremony and wildlife harvesting, sometimes instigated because of hunger in the government settlement. Their only notable employment success in those colonial times occurred when a perceptive superintendent realised that sociable group work was important to Kuninjku. Provided with a blue tractor and trailer, a work crew productively collected rubbish from the communal kitchen and dumped it into a nearby creek.

In the early 1970s, with the change of policy from assimilation to selfdetermination (as defined by the state) and land rights, most Kuninjku people moved back to live and work on their country. When I lived with a small group averaging just 32 people at Mumeka in 1979 and 1980, they clearly differentiated their own work from Balanda forms. Their work was highly flexible, unsupervised and pleasurable; the latter was supervised, subject to relations of white domination and generally to be avoided on an ongoing basis. Indeed, Kuninjku were, and remain, happy for Balanda to undertake certain forms of work that require skills that they do not possess and that require hierarchical forms of organisation and the exercise of workplace authority.

I collected information over one annual seasonal cycle about work effort (using time allocation techniques), the organisation of labour, dietary intake, sources of market and non-market income and expenditure patterns. ${ }^{10}$ This research greatly augmented earlier experimental research undertaken by Fred McCarthy and Margaret McArthur in 1948 at nearby Fish Creek (or Kunnanj) with a group of related Aboriginal people. These earlier data were used by Marshall Sahlins to make his influential argument

9 Sahlins, Stone Age Economics; Altman, Hunter-Gatherers Today.

10 Altman, Hunter-Gatherers Today. 
that the hunter-gatherer domestic mode of production was the original affluent society. ${ }^{11}$ While, like McCarthy and McArthur, I documented that all adults worked three to four hours per day, I also showed that this work extended over seven days a week and was an average across all adults. Hence, I made the case that, as a group, Kuninjku labouring effort was the equivalent of full-time by broader societal standards.

I cannot explore in any detail the Kuninjku mode of production here; however, as an aside, I note the following features that are immediately salient to the issues raised in this chapter. When at Mumeka, I quantified that hunting and gathering was the mainstay of the economy, hence the title of my book Hunter-Gatherers Today. This form of production in turn required people to live in a highly mobile manner, and I documented regular seasonal residential shifts between resource bases. It also required periods of extraordinary hard labouring-work density in hunting, fishing and gathering in hot tropical conditions could be very arduous, as I discovered quickly through participant observation. As I have documented elsewhere, over time, the overall contribution of hunting to livelihood has declined as other sources of cash income from art sales and transfer payments from the state have increased. ${ }^{12}$ Yet, self-provisioning dependent on mobility has remained a crucial aspect of Kuninjku subjectivity. Access to vehicles for mobility for economic, social and cultural reasons is of the highest priority for Kuninjku after meeting immediate survival needs, and earning cash and saving for vehicles is a major motivation for engagement with market capitalism via arts manufacture. ${ }^{13}$

I also examined the organisation of work and showed that it was undertaken in two broad but highly interchangeable forms: individually or with kin, with the latter more common. Everyday work was, and remains, organised by negotiated consensus. Only in ceremonial work was there a willing acceptance of the domination of 'managers' (djunkkay) who organised ritual workers and still do; people work at ceremony for the ceremonial boss and also today, at Christian Fellowship, people work hard with song and dance for a new additional boss 'Jesus'.

11 Sahlins, Stone Age Economics.

12 Altman, 'From Kunnanj'.

13 Altman and Hinkson, 'Mobility and Modernity'. 
In the last 30 years, labour arrangements have changed in many ways; however, for Kuninjku, effective work is still organised either on one's own or with one's immediate family or in small groups, preferably of other Kuninjku. The former is especially evident in arts practice; in the last three decades, arts production has grown rapidly, with Kuninjku being the most prolific and successful artists in the region. The latter is evident in hunting for food in the bush, but also in Maningrida. For example, a group of Kuninjku women dominate at the local Babbarra Women's Centre and form a sociable team of closely related and successful textile screen printers. At outstations, there are almost no formal jobs beyond a handful of part-time teaching assistants.

My focus in this chapter is on materially productive forms of labour, mainly because this is the point of articulation with policy concerns about formal employment. Yet, from the emic Kuninjku perspective, such labour is little differentiated from spiritual work at ceremonies and reproductive and nurturing labour. What is important is that acceptable labour for Kuninjku has some prerequisites if it is to be sustainable: it must be flexible, allowing high rates of residential mobility; negotiated (with supervisors, Bininj or Balanda); and secondary to family and ceremonial obligations. This could be termed the Kuninjku work values regime. It is a regime that is based on positive reciprocity with kin and 'balanced' exchange with the market (i.e. art for cash, which is often influenced by the soundness of social relations with the arts manager), and seeks to avoid negative reciprocity and exploitative relations. To deploy David Graeber's schema explaining the moral grounds of economic relations, Kuninjku labouring is based on everyday sharing and avoids hierarchy and domination. ${ }^{14}$

From 1979, this flexible Kuninjku labouring regime has been strongly supported by BAC, especially since 1989 with its application of rules for managing the CDEP scheme in a suitably flexible manner. BAC's goals include the maintenance of language, culture and traditional practice; community development; promoting the welfare of its members; and services provision. BAC deployed its corporate capacity to assist Kuninjku mainly by using the CDEP scheme to provide a form of unconditional income support when people were at outstations, and by effectively marketing Kuninjku art via Maningrida Arts and Culture, the main 
regional institution for productive (rather than consumptive) engagement with global capitalism. Coincidentally, it also provided considerable logistical support for ceremonial work. ${ }^{15}$

Following the Intervention in 2007, BAC's capacity to support flexible labouring declined markedly - the CDEP scheme came under discursive attack and unhelpful reform, and BAC's main export enterprise, the globally renowned Maningrida Arts and Culture, declined in profitability in the wake of the global financial crisis. Simultaneously, local forms of political representation were systematically diluted -an Australian Government official was installed as the supreme regional political authority and agent of surveillance for Canberra.

From the late 1990s, the Australian Government has increasingly represented remote-living Aboriginal people like the Kuninjku as welfare dependent, passive and in social and moral decline. These people have been framed in national discourse and the popular media as savage and primitive and as problematic parents. This was part of the rationale for the 'national emergency'. Hence, they needed strict policing and disciplining in work, education, expenditure of welfare income, ordered housing and so on if they were to be human in the same way as other citizens within Australia's late liberal order. ${ }^{16}$ Simultaneously, the language of rights and responsibilities has emerged; however, it is applied to people who regard the rich Australian state as responsible for their wellbeing and have no notion of reciprocity as being a part of any regionally recognised social compact.

Subsequently, a neoliberal trope has emerged that emphasises the need for greater exposure to market capitalism, individualism, entrepreneurship and private accumulation. Places like Maningrida have been identified for special attention because of their relative size and associated visibility. Maningrida, with just over 3,000 residents, is one of the largest Aboriginal townships in the Northern Territory. In early 2009, it was defined for a short time as a 'Territory Growth Town' by the Northern Territory Government. ${ }^{17}$

15 Altman, 'Bawinanga and CDEP'.

16 Macoun, 'Aboriginality and the Northern Territory Intervention'; Anthony, Indigenous People, Crime; Checketts, 'The Pulse of Policy'.

17 Sanders, 'Working Futures'. 
To qualify for development assistance, BAC has increasingly been required to actively participate in this project of improvement. This requirement was resisted for a time; however, more recently, with a change of CEO in 2010, there has been acquiescence. ${ }^{18}$ Like the Australian Government, BAC does not currently recognise or strongly advocate for Kuninjku notions of labour; instead, it mainly subscribes to the state requirement to assist in closing the gaps, and the rhetoric that people on 'sit down' money (i.e. welfare) need to learn to 'stand up', as one BAC manager explained it to me in July 2012.

In the post-Intervention environment, we have seen a twin perspective that is increasingly shared by political and bureaucratic elites residing far away in Canberra and Darwin, and recent powerful Balanda arrivals at Maningrida who occupy managerial and professional positions. First, the promulgation of the myth that there just might be sufficient paid jobs for all to be employed within the region if it were rapidly developed. Second, and alternatively, that there are prospects for people to be trained for employment elsewhere, for example in mines (see Prout Quicke and Haslam McKenzie, this volume). Such perspectives fly in the face of both commissioned consultancy research and census data that document the excess supply of labour in the region.

Therefore, in July 2012, because of a loss of corporate memory and an ignoring of documented history, there was a return to a version of the developmental approach of the 1960s, with a host of small speculative ventures (that failed then) to be revisited-like the chicken and egg farming and vegetable gardens that I observed being developed at Mumeka (as well as other outstations). In the quest to demonstrate that formal labour is being undertaken, workers at Mumeka were all issued with high-visibility work wear, boots and safety sunglasses, illustrative, perhaps, of hard industrial work and a demonstration of modern compliance with occupational health and safety standards, and worn by Kuninjku so that they could be seen labouring. What is more, these new 'development' projects were being incubated on a highly speculative basis without any commercial business planning or assurance that state support would continue. Yet, BAC managers presented these as enterprises with mixed objectives, including training hunter-gatherers in horticulture and

18 This change can be linked in part to the appointment of a developmental CEO who had been actively involved as a government business manager during the Intervention and was a senior member of the Australian Federal Police; he is the CEO who was sacked in July 2012. 
animal husbandry to ensure the 'food security' (a new buzz term) that seasonal hunting and fishing predicated on high labour mobility could not deliver, according to BAC staff. Then there was environmental health improvement, another buzz term in Canberra, hence funding for the pizza ovens and mudbrick barbeques for cooking to replace 'unhygienic' open fires and ground ovens, as explained to me by another Balanda manager.

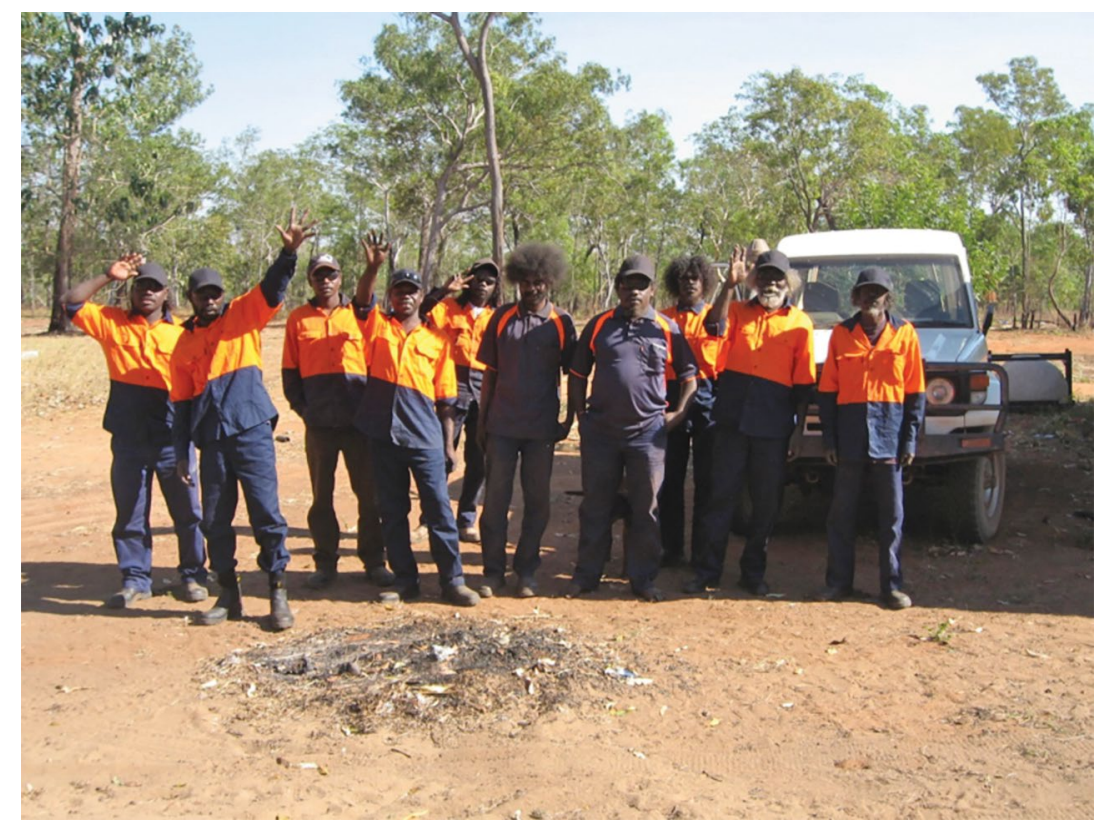

Figure 12.2: The Mumeka work crew, July 2012.

Source: Photograph by Jon Altman.

I visited Mumeka several times during my regional field work in July 2012 to observe and discuss progress. As some members of the Mumeka work crew (and a Balanda tradesman) needed to daily commute an hour each way from Maningrida, only two or three hours a day were devoted to actual labouring in these new ventures. Kuninjku people at Mumeka were thrilled by the largesse that was provided with public funds but were not convinced about the likely sustainability of any of the projects; they were just going with the flow. I observed on several occasions that as soon as formal labouring was completed, people headed off to hunt and fish, which they did with success-long-necked turtles, barramundi, pig, buffalo, file snakes and ibis were evident-while the work crew that had driven out rushed back to Maningrida to their families and to shop, participating 
in speculative hunting and fishing on the way. Paradoxically, and likely unintentionally, in looking to 'develop' Mumeka and impose Western forms of labouring on Kuninjku, both the state and BAC were facilitating hyper-mobility funded by a government program. Members of the work crew who lived at Mumeka assured me that the high-visibility clothing was removed for after-hours hunting, not a bad idea with dangerous feral water buffalo and pigs a common target as a food source.

\section{Interpretative Frames for Understanding Recolonisation}

The Australian state is deploying a mix of old colonial and new market mentalities as it looks to recolonise remote Aboriginal spaces, sponsor 'new' development projects, and attempt new ways to immobilise people and their labour. Yet again, a pathway to late modernity for remote-living Aboriginal people is being charted by distant political and bureaucratic players using local agents to implement somewhat fanciful employmentcreation projects. These untrustworthy trustees who always promise, but rarely deliver, seek to render deep development problems technical, to paraphrase James Ferguson, ${ }^{19}$ choosing to turn a blind eye to past and present failures as the ideological rationales for improvement schemes become entangled with a messy world.

I have used the prism of labouring here to examine the political struggle to reshape norms and values away from what is perceived as the unstable, communal Aboriginal fix, to the stable, Western market fix, as Tania Murray Li might say, ${ }^{20}$ except that no one seems to know what the market fix might look like in this region, and no one who exercises power really seems to know what people actually do. For Kuninjku, occupationally flexible labouring in hunting and fishing and arts production-activity that is unrecognised as 'real' work-greatly improves the quality of people's lives and livelihoods. However, official employment statistics are constructed in a manner incapable of reflecting such regional realities and thus reflect instead the urgent discursive goal to close employment gaps.

19 Ferguson, The Anti-Politics Machine.

$20 \mathrm{Li}$, The Will to Improve. 


\section{Neoliberal Governmentality}

Loic Wacquant has argued, persuasively in my view, that neoliberalism is not an economic but a political and cultural project. ${ }^{21}$ In Arnhem Land we see the political rationality of governmentality looking to improve social conditions by seeking to alter Kuninjku conduct and habits, deploying new technologies, institutions and forms of knowledge seeking to create self-interested subjects with a progressive desire for industry (be it chicken eggs or market gardens); stable formal employment and regular work patterns; and individual, not group, accomplishment. It is no coincidence in this reading that there are many more police deployed in Maningrida and that regulatory barriers are placed in the way of those who wish to pursue other ways of being; getting a gun licence or getting a driving licence or registering a vehicle essential for hunting are all bureaucratic nightmares in remote outposts like Maningrida.

Wacquant sees neoliberal governmentality as the art of shaping populations and the self to conform to the market, even if the market might be miniscule as in 'Territory Growth Towns' like Maningrida or even more so at Mumeka: its institutional core consists of an articulation of state, market and citizenship that harnesses the first to stamp the second on the third. I do not explore Wacquant in any detail here, but there is much in his framework that resonates strongly with what the state is looking to implement in remotest Australia: liberty for those at the top, punitive paternalism for those at the bottom; idleness as a perceived social problem for the unworthy unemployed; ethnic disciplining; and the communicative mission of projecting asserted sovereignty into previously under-governed geographic spaces.

James Ferguson also interprets neoliberalism as a political project, but he challenges progressive anthropologists (such as myself) to turn neoliberal logic to progressive practical use. ${ }^{22}$ In urban southern Africa, Ferguson suggests that black populations are not, and are unlikely to become, formal wage labourers; local livelihoods are being decimated owing to the valorisation of formal work and the conditional provision of supervised workfare and endless training sponsored by the state that clings to the

21 Wacquant, 'Three Steps'.

22 Ferguson, 'The Uses of Neoliberalism'. 
false hope that trained people will somehow magically find suitable employment irrespective of politico-economic structural constraints. His observations resonate with the Arnhem Land case examined here.

What is especially revealing in the Maningrida situation is how the powerful Australian state based in Canberra, the national capital, wields authoritarian managerialism to directly influence development in remote regions. Yet, the responsibility for implementing this impossibly difficult governmental policy is devolved to local organisations like BAC.

From its formation in 1979 to 2007, BAC occupied a difficult position, trying to constantly mediate between the state and its Aboriginal members over the delivery of contested forms of development and labouring. This tension was managed relatively successfully for a variety of reasons including an ability to attract committed senior staff who stayed for long periods of time and were sympathetic to the priorities of local people. However, in the post-Intervention era, the culture of the organisation has shifted as it has increasingly adopted a bureaucratic rationality that locally mirrors the policies of the state. In recent years, it has attracted a revolving door of staff, many of whom lack a commitment to local control and are far more self-interested than they were in the past; most only last a short time and some even fly-in and fly-out from Darwin, where BAC established an ancillary office for a time. In general, most people working for $\mathrm{BAC}$ today are more interested in the jobs package and less interested in local histories, complexities and cultures. This has resulted in considerable conflict, with the sacking of the CEO by the all-Aboriginal board in July 2012 being just one example. As the state promulgates 'false capitalist' solutions to deeply entrenched development challenges, it is complicit in attracting (and aiding and abetting) managers who seek to riskily mimic state ideology and put forward proposals for risky projects like vegetable gardens, chicken coops and pizza ovens.

\section{Moral Economy}

The concept of moral economy, as Chris Hann reminds us, has been applied to criticise economism and highlight the values that have provoked sections of society to resort to political action and behaviour that puts the long-term values of community before the short-term value of individual 
utility. ${ }^{23}$ In his early work, James Scott argues that peasants have a strong conservative ethic that prioritises the subsistence needs of all members of local communities. Scott suggests that peasants in South-East Asia are risk averse and driven by a safety-first principle, and that they have strongly held beliefs in the moral right to subsistence and equitable access to land; yet, he is at pains not to romanticise such economic relations. ${ }^{24}$ Initially, Scott argued that, in situations in which this moral economy was threatened, peasants were likely to rebel; however, in later work, he demonstrated that more subtle forms of resistance might be deployed. ${ }^{25}$ More recently, Scott has argued that some groups maintain a high degree of mobility and move to ungoverned spaces when their 'subsistence ethic' ideology is threatened by authority. ${ }^{26}$

Following Scott, I deploy the concept of moral economy as one analytical means to explain the historic transformation of Kuninjku labouring and what is occurring in the present. I do this in part by using a model of hybrid economy that illustrates how Kuninjku people have simultaneously balanced their domestic mode of production based on subsistence with the requirements of market capitalism and the state. My local theorisation looks to transcend what I see as the false dichotomy between customary economy and market economy, the former embedded and ruled by consensual social norms, the latter disembedded and ruled by impersonal market forces in a distinction reminiscent of that made by Karl Polanyi. ${ }^{27}$ The contemporary Kuninjku economy is thoroughly transformed from any 'traditional' or 'pre-colonial' form. Yet, this economy remains fundamentally organised by normative rules that emphasise mobile forms of labour that allow hunting, sharing with kin and responsiveness to ceremonial obligations. The everyday application of such rules is not free of tensions and conflict.

Returning to the central issue of labouring; the state is looking to impose individual forms of regulated work on Kuninjku people even as its own statistical collections demonstrate that there is insufficient work for everyone, and even as Kuninjku (and others) engage in formal employment in very particular and highly flexible ways. The attempted imposition by the state and its local agents of formal Western work

23 Hann, 'Moral Economy'.

24 Scott, The Moral Economy, 5, 33.

25 Scott, Weapons of the Weak; Scott, Domination and the Arts.

26 Scott, The Art of Not Being Governed.

27 Polanyi, The Great Transformation. 
patterns and rigidity threaten the moral foundations of Kuninjku notions of community and proper behaviour based on a valorisation of family, sharing and participation in ceremony-all actions associated with unpredictable availability for work and residential fluidity. It also threatens the foundations of the hybrid economy that is predicated on the maintenance of customary links to the land for sustenance, and a high degree of continual occupational mobility between formal and informal work activities rather than the expected commitment to sustained employment and occupational specialisation.

As I noted earlier, there is an underlying dominant assumption by the state and its agents of imagined inactivity, whereas Kuninjku life is teeming with economic and social activity and ceremonial life, all being inseparable in the Kuninjku world view. There is also an underlying assumption that Kuninjku and other people in Maningrida are unaware of the global and local manifestations of market capitalism, even though Kuninjku have been acutely observing the comings and goings of Balanda and their demanding labouring regimes for a long time. Increasingly, Kuninjku people watch television, engage with social media and, occasionally, travel, both domestically and internationally, and so they have an acute awareness of different forms of work and which forms they desire and do not.

In Maningrida, Kuninjku see a dual economy demarcated mainly by ethnicity with a growing number of Balandas holding professional and managerial jobs, living in small family units, earning a lot of money, enjoying an endless supply of cash, fully (if not over-) employed and living in a hyper-mobile manner; in recent years, some, especially contractors, fly-in and fly-out like mine workers (see Prout Quicke and Haslam McKenzie, this volume). All this has a different logic to the priorities of Kuninjku. Census data in recent years show that the median Balanda income is over four times that of local Aboriginal people. ${ }^{28}$ Yet, almost without exception, Balanda today do not stay for long-government officials come and go, as do most employees of Aboriginal organisations, some of whom are even foreign backpackers and holders of temporary 457 work visas. Unsurprisingly, such transient visitors lack understanding of local economic history or regional cultural practices, and do not

28 At that time, median individual income for Indigenous adults was $\$ 268$ per week and for nonIndigenous adults $\$ 1,167$ per week. See '2011 Census, Community Profile', Australian Bureau of Statistics, accessed 31 March 2018, www.censusdata.abs.gov.au/census_services/getproduct/census/ 2011/communityprofile/IARE704003?opendocument. 
have any deep local social relationships. While local information on remittances out of Maningrida is not available, one suspects much wealth is transferred out of the region by Balanda even as they participate in the project to fix 'the Aboriginal development problem'. When I asked Kuninjku if they desired to live and work in this way, the response was invariably 'no'-such work represents an unacceptable regulation of life. As one (now deceased) friend, Joshua Jununwangga, put it to me: 'I am far too busy for a full-time Balanda job.'

\section{Conclusion}

A moral panic, the reported abuse of children, accompanied the Northern Territory Intervention; consequently, issues of morality now permeate all aspects of policy, including an emerging intolerance of culturally different ways of labouring. There is much here that is reminiscent of Charles Fourier's nineteenth-century critique of the resistance by wage labourers to the boring, repetitive work of early capitalism versus the flexible, attractive labour that could provide greater freedom if accompanied by a guaranteed income (that the CDEP scheme at outstations used to provide). Fourier insisted that only free work can be pleasurable. ${ }^{29}$ Kuninjku would agree. What is clear today is that the state is looking to construct subjectivity for Kuninjku by deploying the tropes of rigid paid work and responsibility. Implementation of this paternalistic project is being devolved in large measure to local organisations, like BAC. In the process, a historically successful Aboriginal organisation is being coopted and depoliticised because of its financial dependence on the state.

The growing space that is being created (rather than reduced) between Bininj and Balanda views on labouring in remote places like Maningrida is concerning, as it inadvertently allows for what can be termed reckless use of public funds; more harshly, it enables a form of petty corruption and waste that is state sanctioned. Pursuit of the state's quest to close the employment gap leaves much room for the promotion of false capitalist endeavours. Those who quietly acquiesce to the state project can be rewarded with largesse, while those who challenge its validity are punished - a form of moral hazard that resonates with what some have observed in weak states, not in supposed 'strong' states like Australia. ${ }^{30}$

29 Spencer, 'Work in Utopia'.

30 Weigratz, 'Fake Capitalism'; Ferguson, 'The Uses of Neoliberalism'. 
Maningrida is becoming a more permissive place, with more and more outsiders coming and going and fewer checks and balances today than during the 'self-determination' era when a legally enforced permit system could be deployed to monitor the movements of outsiders. Kuninjku are, at times, bewildered when in Maningrida by the comings and goings of unknown people with unknown purposes and sometimes are keen to escape for a sojourn at outstations, just for some welcome bush order; when in town, they are becoming less visible, often working indoors on arts production to avoid recruitment for some well-intentioned training program to equip them for forms of labour for which they have no desire.

What is missing in much of this debate is recognition that groups like the Kuninjku have made extraordinary transformations in a very short time. For over a decade, they were responsible for the bulk of the region's only commodity exports: art. As such, they were the ones most engaged with global capitalism. However, they did this in their own way and with a degree of sensible caution, ensuring that the other key sector of their domestic economy, self-provisioning, remained intact.

In July 2012, Kuninjku were willing to don high-visibility safety clothing symbolic of hard work, hoping, perhaps, that they might be sighted from the nearby flat-bladed vehicular track by visiting officials. They struggle to retain key elements of their plural economy even when facing requirements to engage in monochromic forms of Western labour; their early response to the 'new' development approach and its labouring requirements is highly pragmatic and adaptive, even humorous. Yet, it also demonstrates a resignation that enhanced engagement with the dominant state is currently required.

In the longer term, if one is to see a regional dévéloppement durable, a form of development that is beneficial and lasts, ${ }^{31}$ local political institutions will need to be reactivated to challenge destructive forms of neoliberal state-sponsored economism. One interpretation of my analysis is that it provides some semblance of hope because, even after 55 years of colonisation, decolonisation and, since 2007, attempted recolonisation (to 2012), Kuninjku people have managed through their agency and alliances to mould forms of hybrid economy and associated flexible labour relations that accord with their desires to remain at home and near, or on, ancestral lands. The Kuninjku case that I present here is not intended as

31 Hart and Padayachee, 'Development', 61. 
some heroic tale of the destruction of the hegemony of neoliberal ideas as recently described by David Graeber. ${ }^{32}$ To the contrary, what I have described as governmental overreach can have, as has subsequently become apparent, deeply destructive consequences with human casualties.

\section{Postscript: March 2018}

I have been back to the Maningrida region nine times since July 2012, the visit during which I observed what I now interpret as a tipping point in the absurd neoliberal governance of remote places like Mumeka. There have been two federal elections and the policy landscape has worsened quite significantly in my view. BAC has been in and out of special administration; it ran into financial difficulties owing to developmental overreach and wasteful projects that meant it could not meet its obligations to creditors.

It is difficult to explain why the Australian Government, with all its surveillance apparatus, would have allowed the situation at BAC-one of the largest and most successful Indigenous corporations in remote Australia - to eventuate. It seems to me that there is a brutal political conflict underway, driven by the deployment of excessive state power, that is looking to escalate the project of behavioural modification on people like the Kuninjku using community-based organisations like BAC as the local blunt instrument to oversee the transformation of what is perceived as unproductive welfare-dependent labour into imagined paid employment or, at the very least, to discipline the jobless.

From 1 July 2013, the CDEP scheme was incorporated into the new Remote Jobs and Communities Program launched by the Gillard Government in its dying days. Then, with a conservative government elected in September 2013, the remnants of the scheme that had been 'grandfathered' were swept away. First, there was a review of Indigenous employment and training programs headed by a mining magnate, Andrew Forrest, to plough the turf for reform. ${ }^{33}$ Next, there was implementation of his recommendations, which included the end of the flexible CDEP

32 Graeber, 'The Shock of Victory'.

33 Forrest, Creating Parity. 
scheme for all on 1 July 2015 and its replacement by the cynically renamed Community Development Program (CDP) that has little similarity to the old scheme. ${ }^{34}$

A combination of special administration and policy reform has seen BAC become more and more an 'employment and training' provider selected by competitive tender, and less an outstation resource agency that delivered forms of appropriate development to support flexible ways of living and labouring to its membership. BAC's financial rehabilitation appears successful. However, as with all structural adjustment and financial bailouts, this has come at a cost: loss of organisational autonomy, new externally imposed modes of operation and requirements to comply with CDP guidelines that focus on paid employment and the omnipresent Closing the Gap paradigm.

CDP is a 'work for the dole' scheme that requires able-bodied people aged 15-49 years to work five hours a day, five days a week in a range of work-like activities with Newstart Allowance (the dole) as remuneration. Such stringent work requirements eliminate other livelihood possibilities, especially self-provisioning on country away from Maningrida. BAC is paid a bonus if it places jobless participants in sustainable mainstream employment (defined as 13- and 26-week outcomes). BAC is also paid for alerting Centrelink if participants fail to turn up for make-work, training or designated appointments-welfare payments are docked one day's pay for each 'no-show' occurrence. To date, BAC, like other providers distributed across regional and remote Australia, has been more effective in alerting Centrelink about no-shows than in delivering jobs to a massive caseload of nearly 1,000 jobless adults in a regional economy that has few jobs. ${ }^{35}$

The old colonial logic of the 1960s has re-emerged in a punitive and impoverishing manifestation. Using a stick-and-carrot ${ }^{36}$ behavioural approach, it is assumed that surplus Aboriginal labour can be disciplined and trained to make it job ready. Alternatively, it is assumed that people will migrate for employment even if only to escape this paternalistic regime. In a highly contradictory and destructive manner, politicians and their

34 These recommendations were implemented despite a robust critique of the review process and its recommendations, see Klein, 'Academic Perspectives on the Forrest Review'.

35 See Jordan and Fowkes, 'Job Creation and Income Support'.

36 The normal order of this phrase has been intentionally reversed to indicate that there is currently plenty of stick and little carrot. 
officials in Canberra are promoting an employment pathway for jobless Aboriginal people like the Kuninjku that recent official information from the 2016 Census clearly informs them does not exist. ${ }^{37}$ At the same time, the mainstream media and policy discourse laments the destructive effects of inactivity and the consequences for wellbeing of deepening poverty. Again and again the assumption is made that the relational norms and values adhered to by people like the Kuninjku will be broken and will dissipate when confronted by a powerful discursive trope that promises much and delivers little other than punishment in the form of 'no-show' penalties. There is currently no basis for the belief that market capitalism will blossom in the Maningrida region with employment for all and associated wealth creation. This is just an imagined procedural fix based on ideological blind faith that has no basis in regional reality.

The modern state and its bureaucratic apparatus might look to depoliticise and control local organisations like BAC and people like the Kuninjku but, as Tania Murray Li has illustrated with her work in Indonesia, local groups remain deeply political and capable of subverting imposed plans. ${ }^{38}$

This raises two important questions: How might maladapted Western institutions, like punitive welfare to move people to rigid formal employment, be refigured to facilitate more effective flexible forms of livelihood? The CDEP scheme, which was replete with postcolonial possibility, has now been eliminated by the settler colonial state. ${ }^{39}$ The second question is, to paraphrase Erik Olin Wright, how might 'real utopias be envisioned' for people like the Kuninjku? My research for the last three decades has focused on the deployment of local Kuninjku labour for livelihoods that accord with their aspirations. I end by pondering how a livelihoods approach might be restored for the Kuninjku community and other Aboriginal people living in very remote parts of Australia.

37 A summary of employment data for the three census, 2006, 2011 and 2016, shows that the Indigenous employment/population ratio declined from 26 per cent in 2006 to 18.4 per cent in 2016, having risen slightly to 34 per cent in 2011. The comparative non-Indigenous figures are 95.5 per cent, 91.4 per cent and 88.9 per cent. The Indigenous unemployment rate rose from 17.2 per cent in 2006 to 34 per cent in 2016, even as the labour force participation rate declined from 31.4 per cent to 22.6 per cent. All figures from 'Community Profiles', Australian Bureau of Statistics, accessed 15 March 2019, www.abs.gov.au/websitedbs/censushome.nsf/home/communityprofiles?opendocument\&navpos=230.

$38 \mathrm{Li}$, The Will to Improve.

39 Jordan, Better than Welfare? 
A first requirement is for outsiders to recognise local economic realities and the political imperative to restore social power to community organisations. A second might be to recognise the sociological reality that locally dominant non-capitalist imperatives, so evident in flexible labour arrangements, persist - they cannot just be wished or assumed away, as inconvenient as this may be to the state project of disciplining and neoliberalising labour.

My latest visits to Mumeka were in July 2017 and July 2018. The pizza oven was still there, in sound condition and still unused, a fixture embedded in the landscape. The market gardens are overgrown and the trickle irrigation irreparable. The wooden chicken coops, reputed to have been made in Denmark, are in fragments. There were no people at Mumeka; the residents were scattered, some living in Maningrida, some elsewhere at ceremony. Mumeka was a small flourishing place when I first went there in 1979; in 2012 it was abuzz with developmental excitement. It is now just seasonally occupied.

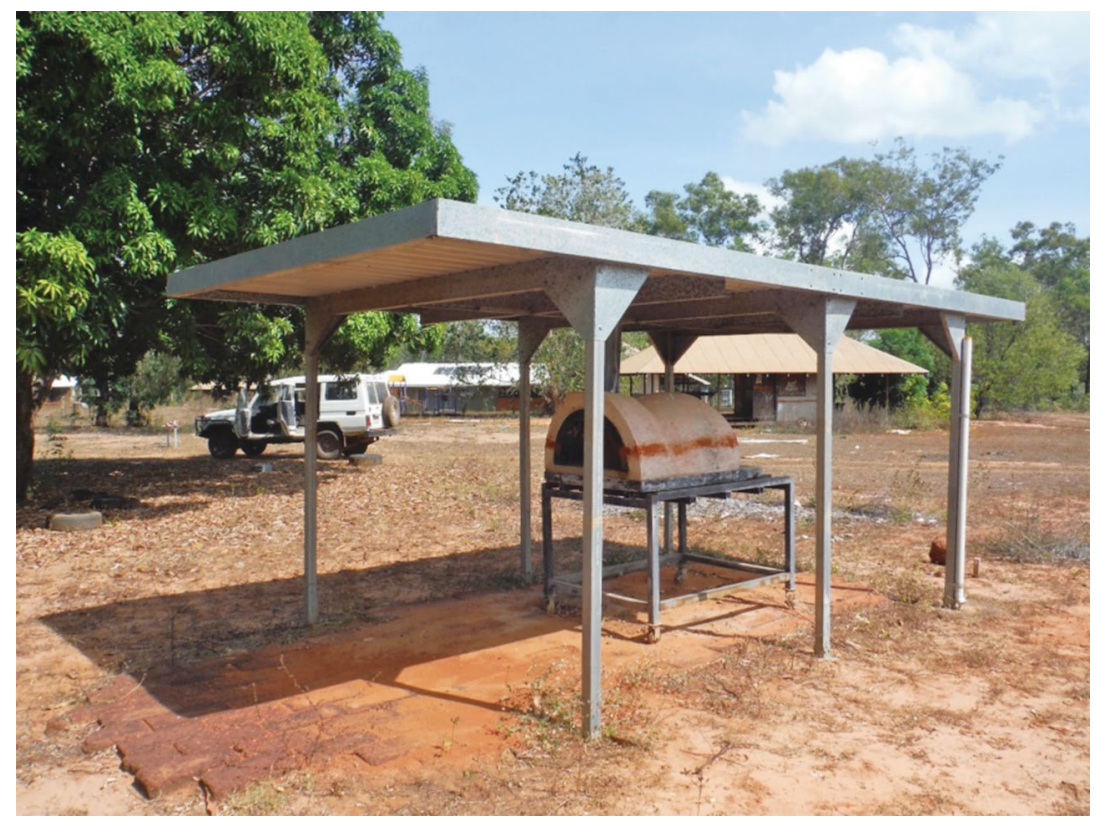

Figure 12.3: The pizza oven at Mumeka, July 2017.

Source: Photograph by Jon Altman. 
In the present, the disjunctures between Kuninjku and Western notions of what constitutes acceptable forms of labour, and the roles that labour mobility and migration might play, are wider than ever. The Australian state is looking to close statistical employment gaps and reduce welfare dependency. This goal requires that people like the Kuninjku either reduce their regional mobility (especially between the township of Maningrida and outstations) and participate in Western forms of formal employment when it is available or migrate for employment. Neither option is currently acceptable to Kuninjku. Paradoxically, it is Balanda and, to a far lesser extent, non-local Indigenous people who migrate to Maningrida to take up employment, but then demonstrate their mobility by only staying for a short time before leaving.

Tragically, the recolonisation project has been highly destructive of the regional forms of plural economy that were evolving. Kuninjku people today are more welfare dependent and impoverished than at any time since the colonial state came to stay in central Arnhem Land in 1957, despite state investment in development paraphernalia like pizza ovens, chicken coops and market gardens. The state's agents and personnel come and go, like its policies, which, arguably, have had more adverse effects than ever on people like the Kuninjku who have stayed.

\section{Bibliography}

Altman, Jon. 'Basic Income for Remote Indigenous Australians: Prospects for a Livelihoods Approach in Neoliberal Times'. In Basic Income in Australia and New Zealand: Perspectives from the Neoliberal Frontier, edited by Jennifer Mays, Greg Marston and John Tomlinson, 179-205. Basingstoke: Palgrave Macmillan, 2016. doi.org/10.1057/9781137535320_9.

. 'Bawinanga and CDEP: The Vibrant Life and Near Death of a Major Aboriginal Corporation in Arnhem Land'. In Better than Welfare? Jobs and Livelihoods for Indigenous Australians after CDEP, edited by Kirrily Jordan, 175217, Canberra: ANU Press, 2016. doi.org/10.22459/CAEPR36.08.2016.07.

. 'From Kunnanj, Fish Creek, to Mumeka, Mann River: Hunter-Gatherer Tradition and Transformation in Western Arnhem Land, 1948-2009'. In Exploring the Legacy of the 1948 Arnhem Land Expedition, edited by Martin Thomas and Margo Neale, 113-34. Canberra: ANU E Press, 2011. doi.org/ 10.22459/ELALE.06.2011. 
- Hunter-Gatherers Today: An Aboriginal Economy in North Australia. Canberra: Australian Institute of Aboriginal Studies, 1987.

. "“The Main Thing Is to Have Enough Food": Kuninjku Precarity and Neoliberal Reason'. In The Quest for the Good Life in Precarious Times: Ethnographic Perspectives on the Domestic Moral Economy, edited by Chris Gregory and Jon Altman,163-96. Canberra, ANU Press, 2018. doi.org/ 10.22459/QGLPT.03.2018.08.

Altman, Jon and Melinda Hinkson. 'Mobility and Modernity in Arnhem Land: The Social Universe of Kuninjku Trucks'. Journal of Material Culture 12, no. 2 (2007): 181-203. doi.org/10.1177/1359183507078122.

Anthony, Thalia. Indigenous People, Crime and Punishment. Milton Park, Abingdon: Routledge, 2013. doi.org/10.4324/9780203640296.

Checketts, Juliet. 'The Pulse of Policy: Mapping Movement in the Australian Indigenous Policy World'. PhD thesis, The Australian National University, 2016.

Commonwealth of Australia. 'Closing the Gap Prime Minister's Report 2018'. Canberra: Department of Prime Minister and Cabinet, 2018.

Ferguson, James. The Anti-Politics Machine: 'Development', Depoliticisation and Bureaucratic Power in Lesotho. Minneapolis: University of Minnesota Press, 1994.

—. 'The Uses of Neoliberalism'. Antipode 41, S1 (2009): 166-84.

Forrest, Andrew. The Forrest Review: Creating Parity. Canberra: Department of Prime Minister and Cabinet, 2014.

Garde, Murray. Culture, Language and Person Reference in an Australian Language. Amsterdam: John Benjamins Publishing Company, 2013.

Graeber, David. Debt: The First 5,000 Years. New York: Melville House Publishing, 2010.

—. 'The Shock of Victory'. In Revolutions in Reverse: Essays on Politics, Violence, Art, and Imagination, 11-30. Minor Compositions, London 2011.

Hann, Chris. 'Moral Economy'. In The Human Economy: A Citizen's Guide, edited by Keith Hart, Jean-Louis Laville and Antonio David Cattani, 187-98. Cambridge: Polity, 2011.

Hart, Keith and Vishnu Padayachee. 'Development'. In The Human Economy: A Citizen's Guide, edited by Keith Hart, Jean-Louis Laville and Antonio David Cattani, 51-62. Cambridge: Polity, 2011. 
Hinkson, Melinda. 'Introduction: In the Name of the Child'. In Coercive Reconciliation: Stabilize, Normalise, Exit Aboriginal Australia, edited by Jon Altman and Melinda Hinkson, 1-12. Melbourne: Arena Publications, 2007.

Jordan, Kirrily, ed. Better than Welfare? Jobs and Livelihoods for Indigenous Australians after CDEP. Canberra: ANU Press, 2016. doi.org/10.22459/ CAEPR36.08.2016.

Jordan, Kirrily and Lisa Fowkes. 'Job Creation and Income Support in Remote Indigenous Australia: Moving Forward with a Better System'. CAEPR Topical Issue No. 2/2016. Canberra: Centre for Aboriginal Economic Policy Research, ANU, 2016.

Klein, Elise, comp. 'Academic Perspectives on the Forrest Review: Creating Parity'. CAEPR Topical Issue No. 2/2014. Canberra: Centre for Aboriginal Economic Policy Research, ANU, 2014.

Li, Tania Murray. The Will to Improve: Governmentality, Development and the Practice of Politics. Durham: Duke University Press, 2007. doi.org/10.1215/ 9780822389781.

Macoun, Alissa. 'Aboriginality and the Northern Territory Intervention'. PhD thesis, University of Queensland, 2012.

McCarthy, Frederick and Margaret McArthur. 'The Food Quest and the Time Factor in Aboriginal Economic Life'. In Records of the American-Australian Scientific Expedition to Arnhem Land, Volume 2, Anthropology and Nutrition, edited by Charles Mountford, 145-94. Melbourne: Melbourne University Press, 1960.

Northern Territory Government. Maningrida: Jobs Profile 2011. Darwin: Department of Business and Development.

Polanyi, Karl. The Great Transformation. New York: Fararr and Rienhart, 1944.

Sahlins, Marshall. Stone Age Economics. Chicago: Aldine and Atherton, 1972.

Sanders, W. 'Working Futures: A Critique of Policy by Numbers'. CAEPR Working Paper No. 72/2010. Canberra: Centre for Aboriginal Economic Policy Research, ANU, 2010.

Scott, James. The Art of Not Being Governed: An Anarchist History of Upland Southeast Asia. New Haven: Yale University Press, 2009.

- Domination and the Arts of Resistance: Hidden Transcripts. New Haven: Yale University Press, 1990. 
The Moral Economy of the Peasant: Rebellion and Subsistence in South East Asia. New Haven: Yale University Press, 1976.

- Weapons of the Weak: Everyday Forms of Peasant Resistance. New Haven: Yale University Press, 1985.

Spencer, David. 'Work in Utopia: Pro-Work Sentiments in the Writings of Four Critics of Classical Economics'. The European Journal of the History of Economic Thought 16, no. 1 (2009): 97-122. doi.org/10.1080/09672560802707449.

Strakosch, Elizabeth. Neoliberal Indigenous Policy: Settler Colonialism and the 'Post-Welfare' State. Basingstoke: Palgrave Macmillan, 2015. doi.org/10.1057/ 9781137405418.

Wacquant, Loic. 'Three Steps to a Historical Anthropology of Actually Existing Neoliberalism'. Social Anthropology 20, no. 1 (2012): 66-70. doi.org/10.1111/ j.1469-8676.2011.00189.x.

Wiegratz, Jörg. 'Fake Capitalism? The Dynamics of Neoliberal Moral Restructuring and Pseudo-Development: The Case of Uganda'. Review of African Political Economy 37 (2010): 123-37. doi.org/10.1080/03056244. 2010.484525 .

Wright, Erik Olin. Envisioning Real Utopias. London: Verso, 2010. 
This text is taken from Labour Lines and Colonial Power: Indigenous and Pacific Islander Labour Mobility in Australia, edited by Victoria Stead and Jon Altman, published 2019 by ANU Press, The Australian National University, Canberra, Australia.

doi.org/10.22459/LLCP.2019.12 